\title{
19世紀から20世紀前半期までのソウル・京畿地域の 寺院大房の外部空間に関寸る研究 \\ A STUDY ON THE CHARACTERISTICS OF OUTER SPACE OF DAEBANG BUILDING IN BUDDHIST TEMPLES OF SEOUL AND GYEONGGI PROVINCE FROM THE 19TH TO THE MID-20TH CENTURY
}

\author{
金 成 都* \\ Seong-Do KIM
}

The study on the characteristics of outer space of daebang in Seoul and Gyeonggi province could be summarized as follows:

1. In the central domain of temples having been composed of both a main temple and a daebang, the former was regarded as a practical or symbolic worship object of the latter and these two buildings were settled within the distance of $75 \mathrm{ft}$ each other. It is the maximum length between a stage and an auditorium that we can see and listen to the actors on the stage.

2. In case of daebang with side wing room(s), the degree of view looking downward at the front window of it was usually within the limit of $30^{\circ}$, which was the downward angle of easy view permitting us to look out without any movement of one's head or eyes.

\footnotetext{
Keywords : Daebang, Yeombuldang(i.e. Building for praying to Buddha), Korean Buddhist Temples, Modern Times 大房, 念仏堂, 韓国寺刹建築, 近代期
}

\section{1. 序論}

\section{1 研究の背景及び目的}

ソウル・京畿地域の寺院に建立された大房は朝鮮時代末期の念仏 盛行と接待重視という社会的状況にしたかってて仏堂の前に位置した楼 を機能的に分化発展させて念佛用法堂で構成した念仏堂であった。

この大房は当時、坐禅堂及び講学堂と共に三つの法堂の一つとし て寺院の中心領域に構成され、万会田沓 ${ }^{1)}$ の上うな別途の経済的基 盤を整えて、化主という役僧の責任にて寺院の中では完全に独立的に 経営されたのである゙う。これによって建築の空間構成が影響され、仏殿 にも関からず生活ができるように台所や僧房施設などを共に備えた。

この論文はこのような大房”を対象にして、外部空間の分析を通し て、その特性を考察しようとする。これにより当時韓国に形成された 樣々な建築空間特性の中で、大房がある寺院の空間特性を知るものである。

\section{2 研究の範囲及び方法}

この研究では19世紀の純祖朝からソウル・京畿地域の寺院で新たに 登場した複合仏殷になる大房を対象にして、その外部空間で見える建築 特性を考察しようとする。このために19世紀から20世紀前半期まで建立され たもので現存するソウル・京畿地域の20個所の寺院(主仏即と大房が共 に構成された15個所の寺院と大房が主仏殷になる庵子規模の寺院5個所 の大房を対象として分析した。これらを整理したことが表1である。 表1に現れた20個所の寺院の大房の中で18棟は19世紀から1910年以前
まで建立されて現存するもので、残りの2棟は日帝強占期に建立され て現存する大房である。記録を通して日帝強占期にも多数の大房が建 立されたことがかかるが、現存するものはただ奉恩寺、開運寺、興國 寺(高陽市所在)の3個所の寺院でしか見られない。ところで開運寺の大 房の場合移建される時、部分的に原形がかなり変形されて、本来の配置 を把握することができなくなったので、この研究では奉恩寺と興國寺 ${ }^{5)}$ の大房だけを研究対象にした。従って日帝強占期に建立されたもので分 析可能な大房の場合、2棟だけなので、この以前に建立された朝鮮時代 以来の典型的な大房を中心にして分析しながら日帝強占期に建立され た大房に対しては空間特性の変化の有無だけを確認することにした。

この研究と関連して先ず2章では大房の空間構成と類型について考 察する。次に3章では大房の外部空間特性として大房構成寺刹の進入特 性、大房と主仏殿との相互間距離分析及び大房前後面の庭の大きさ分析 などを通ずる視知覚的空間特性に対して分析し、4章で結論を出す。

\section{2. 大房の本面空䦌構成及び類型}

ソウル及び京畿地域の寺院に建立された現存する大房の中でその沿革 が確実なもので一番古いのは1812年にたてられた天竺寺の大房である。

このような天笙寺の大房と共に19世紀以來の現存する大房を対象 にして各構成空間を表2で整理した。

表 2 に大房の平面空間を構成する要素を探れば、クンバン(モンチェ ${ }^{6)}$ の大きい念仏用房)、モンチェの前面とか後面或いは前後面に形成される

\footnotetext{
* 日本大学理工学部建築学科 客員研究員 $\cdot$ 博士 (工学 $) \cdot$ 建築士

A. Researcher of the Dept. of Architecture of Nihon University, Dr. Eng., A Registered Architect
} 


\section{表 1. 研究対象建築物}

\begin{tabular}{|c|c|c|c|c|}
\hline 榑遙 & 焦国 & 建立年代 & 物梦 & 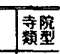 \\
\hline 貥哭虔 & 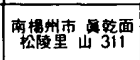 & 11望莠 1800 & 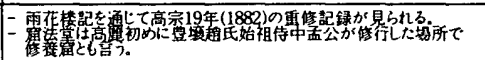 & \\
\hline 慗举 & 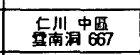 & 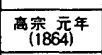 & 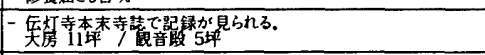 & \\
\hline 䨋替責 & 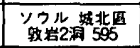 & 惠䆺265) & 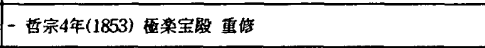 & \\
\hline 繁潜寺 & 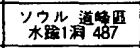 & 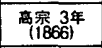 & - 高宗7年(1870) 大椎殿 重要 & \\
\hline 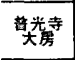 & 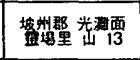 & 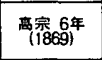 & 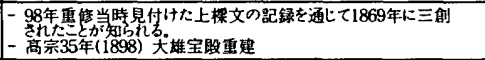 & \\
\hline 㽝楼寺 & 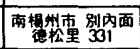 & $\begin{array}{l}\text { 害 } \\
(180)\end{array}$ & 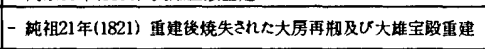 & \\
\hline 桪赤 & 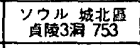 & 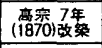 & －1914年 俩类主即再策 & 傕 \\
\hline 慗永幸 & 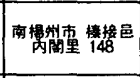 & 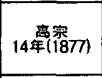 & 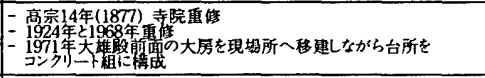 & 㵝 \\
\hline 烈算幸 & 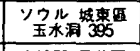 & 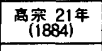 & 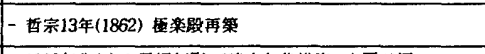 & 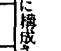 \\
\hline 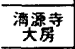 & 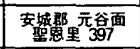 & 1908年 & 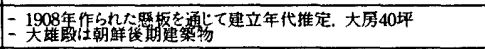 & \\
\hline 留埥 & 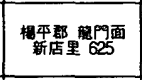 & 1909年 & 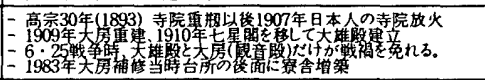 & 箖 \\
\hline 碚寺 & 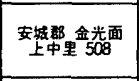 & 蝴解末 & 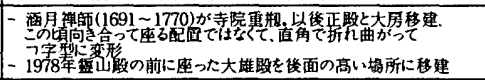 & \\
\hline 地笑劫 & 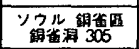 & 胡铬末 & 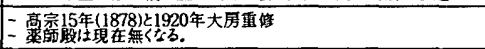 & \\
\hline 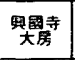 & 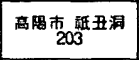 & 日帝挴占期 & 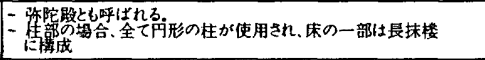 & \\
\hline 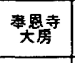 & ソクル江䓟四 & 1941年 & 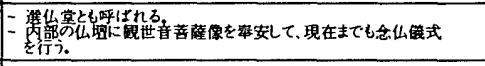 & \\
\hline 笑素 & 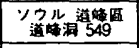 & 1812年 & 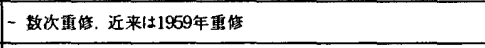 & \\
\hline 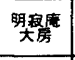 & 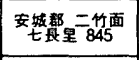 & 1828年 & 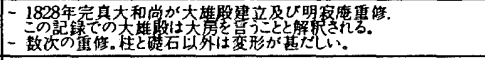 & 牊 \\
\hline 梨通度 & 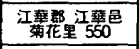 & 1857年 & - 1987年解体 & 撨 \\
\hline 烈水廦 & 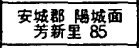 & 1870年頃 & - & 㪈 \\
\hline 學等 & 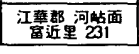 & 1905年 & 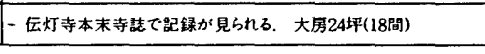 & \\
\hline
\end{tabular}

退抹楼、台所、責任者になる化主及び念仏僧用僧房、右側 ${ }^{7)}$ の接待用 翼楼と左側の僧侶休息用翼楼、それから屋根骹へやとか倉庫のような 付属空間がある。その中で全ての大房ではクンバンと退抹楼、化主用 僧房、台所、そして付属空間が共通に現れるから最も基本的な構成要素 なことがかかる。それからここにクンバン前面へ翼舎が組み立てられ る場合もあり、そうでない場合もある ${ }^{8)}$ 。ここに翼舍が構成される場 合は右側の接客用翼楼だけ作られる場合と共に左側の僧侣休息用翼楼 までも備える場合を見ることができ9)、またこの楼の代わりに抹楼房 とか温突房に構成される特殊な場合もみることができる゙

従って朝鮮時代末期に建立された大房はその空間を構成する基本 構成要素に作られる翼舎の数によって三つの類型に大別される。

先基本構成要素にクンバン前面の左右両側に二つの翼舍が構成 される類型で、興天寺、興國寺(南楊州市所在)、慶國寺、天竺寺、雲 水奄の場合が当てはまり、これをクンバン前面双翼舎形と言える。

次にクンバン前面の右側に一つの翼舍が構成される類型で、見聖 庵、華溪寺、普光寺、興國寺(高陽市所在)、白蓮寺の場合が当てはま ク、これをクンバン前面単翼舎形と言える。明寂庵の大房も同じくこ の類型に属するが、翼舍の位置が左側に構成されたことがわかる。

最後に翼舍が構成されない類型で、石南寺、龍宮寺、奉永寺、爾陀 寺、清源寺、龍門寺、地藏寺、奉恩寺、圓通庵の場合が当てはまり、こ れをクンバン前面無翼舎形と言える。

これらの沿革が知られている中で、最も古い天等寺の大房の場合は クンバンと退抹楼、化主 ${ }^{11}$ や念仏僧の為の僧房、念仏大衆に食事を提供 する台所、それから付属空間の基本的構成要素以外にクンバン前面に 左右両側の翼楼まですへて備えていて、大房の成立初期にはこの様な 兩翼楼を取り揃えた完結となる型式に現れたことが見られる。
表 2. 大房平面楼成

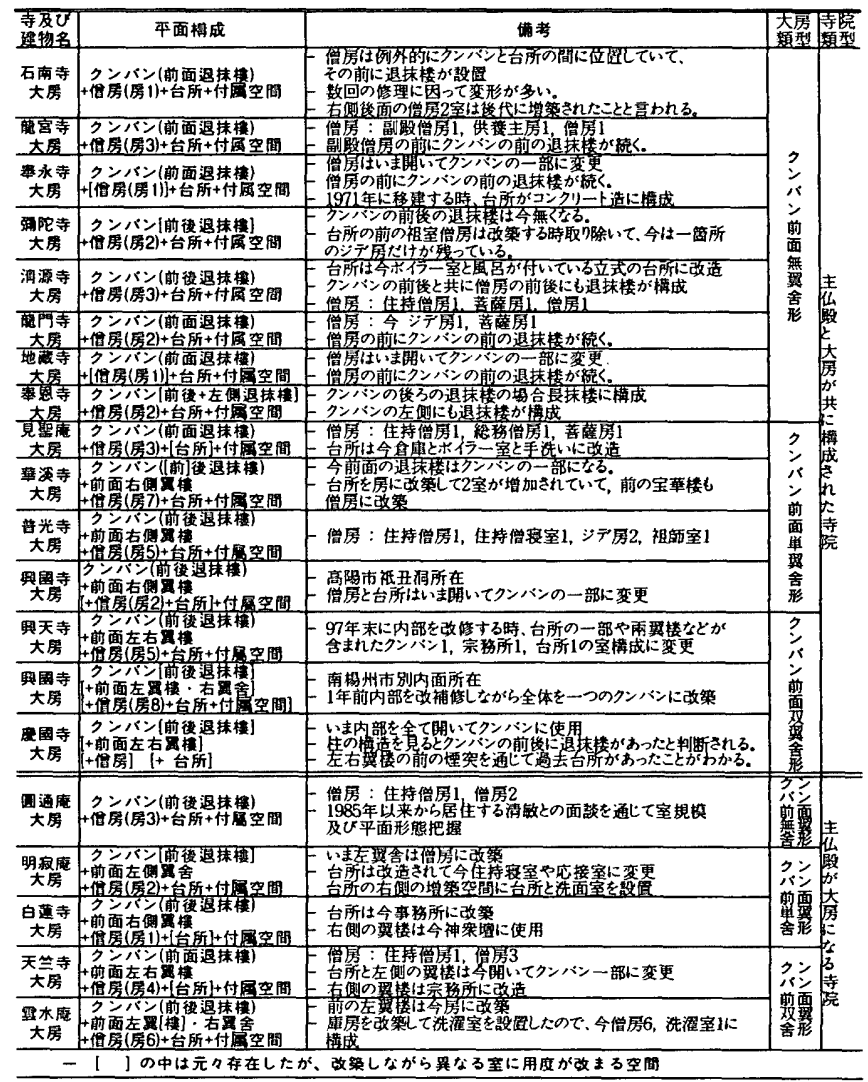

一方表2で僧房の数を見ると、部屋が一つから八つまで構成されることを見 ることができる。ころで大房の中の僧房の場合、間仕切りによって簡単に空間を 分離、結合することができる構造的特性により、今の部屋の分割状態が以前の 場合と一致したと見ることは困難な側面がある。けれどもこのような場合を考慮して も念仏僧の増隇によって様っな僧房数が現われるのを確認することができ、また 大房後面の拡張を通していくらでも部屋の数を增すことができる平面拡張性を 取り揃えた大房の柔軟な構造的優㐁性を探れる。

\section{3. 大房の外部空間特性}

\section{1 大房構成寺踪の進入特性}

19世紀から1945年までに建立された大房が現存しているソウル・京畿地域 の20個所の寺院を対象 ${ }^{12)} に し て 、$ 進入動線と関連して大房の位置での主 要進入方式(図2参照)及び大房の平面空間構成を整理すると表3になる。

朝鮮時代末期に移建して寺院の元の配置がかからない石南寺や1971 年大房を移建して配置が変形された奉永寺、1941年に再建されてから 当時の配置がかからない奉恩寺、1987年解体されてから当時の配置が かからない圓通庵、そして寺院の中で数多くの変形によって元の状態 がわからない龍門寺と地藏寺を除外すると、配置のわかる全て14個所 の寺院の中で10個所で、大房正面に向かって左側進入方式を取っている ことがわかる。またこれらの中で日帝强占期に大房が建立された興國 寺(高陽市所在)でも同様に左側進入方式を取っていることがかかる。

主仏殿 ${ }^{13)}$ と大房が共に構成される寺院の場合大房の左側に進入して 中庭に登って主仏殿及び其他殷閣に達するようになり、主仏殿が大房 になる寺院の場合にも大房から其他殿閣へ行こうとする時は大房の左 側を通して各殷閣に行けることがわかる。このような左側進入方式を 取った寺院の大房では責任者が住む化主用僧房がプライバシーの為に 
表 3. 大房楼成寺院の進入方式

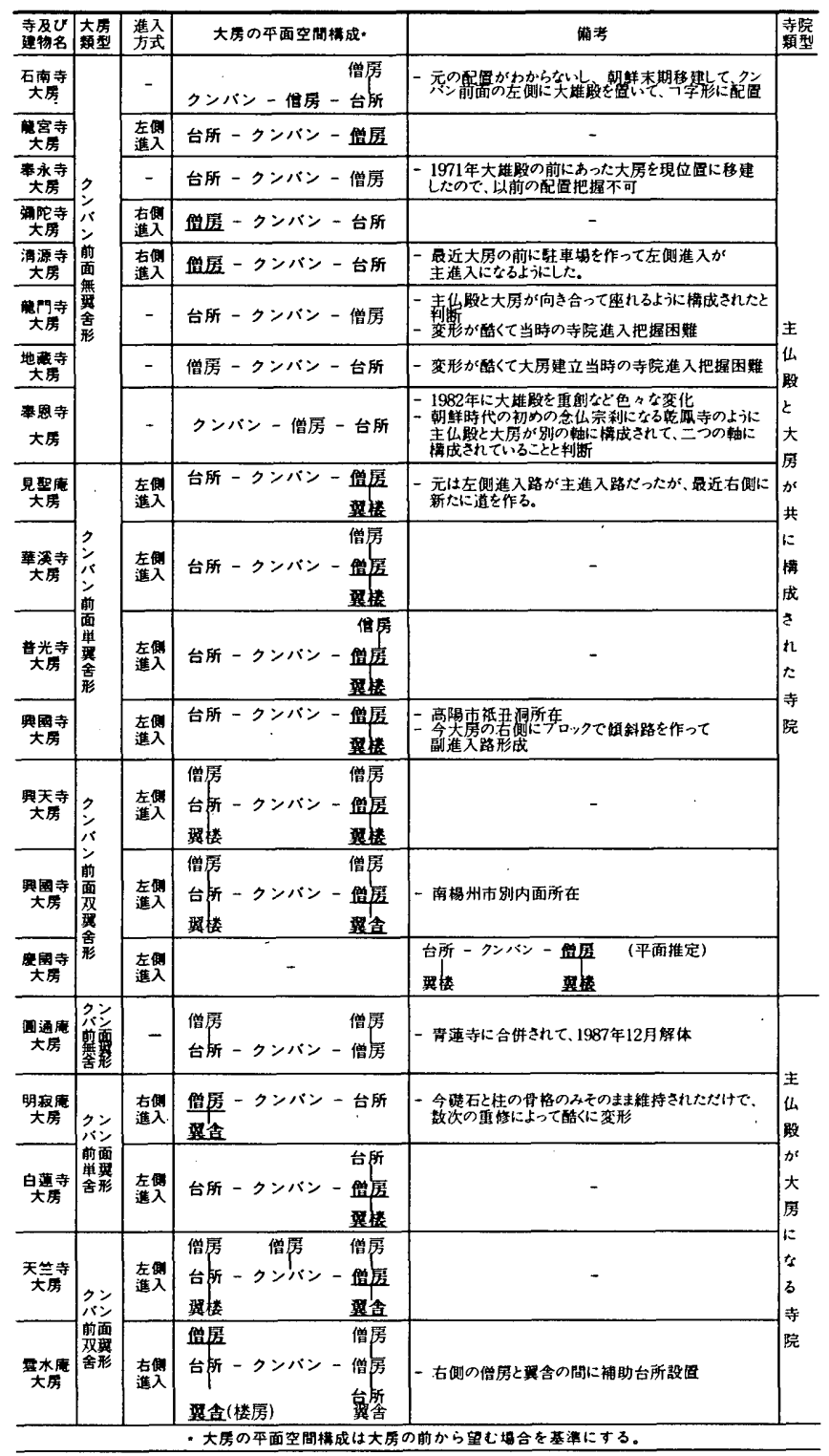

その反対になる右側に構成されていることがわかり ${ }^{14)}$ 、クンバンの前 に翼楼が構成される類型の場合プライバシ一を要する接待用翼楼が同 様に反対になる右側に構成されたことがわかる。そして進入路に向い て左側に台所が構成されたことが見られる。

一方寺院が位置する敷地の状況によって例外的に右側進入をしなけ ればならない場合も4個所の寺院で見られる。主仏殿と大房が共に構 成された韩陀寺及び清源寺や大房が主仏殿になる雲水庵及び明寂庵で このような右側進入方式が見られる。このような寺院の大房でも化主用僧 房はそのプライバシ一の確保の為に進入路の反対になる左側に位㯰されて いて、接待用翼舎が構成された雲水庵及び明寂庵の場合その翼舎はプラ イバシ一の為に進入路の反対になる左側に構成されたことがわかる。そ して進入路に向いて右側に台所が構成 ${ }^{15)}$ れたことがわかる。

従って朝鮮末期以来大房が構成されたソウル・京畿地域の寺院の場合、 主仏殿と大房が共に構成された寺院や主仏殷が大房になる寺院すべてで 中心領域の庭とかその後ろの仏殿人接近する時、左側進入方式を取ることがー 般的な原則であって、大房の空間構成荘素の中でプライバシーが必要な化主用 僧房と接待用翼舎に対して合理的に配虑して計画したことがかかる。孔て日帝

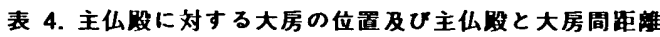

\begin{tabular}{|c|c|c|c|c|}
\hline 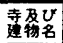 & 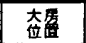 & 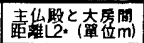 & \multicolumn{2}{|l|}{$\begin{array}{ll} \\
\end{array}$} \\
\hline $\begin{array}{l}\text { 石南寺 } \\
\text { 大为 }\end{array}$ & - & - & 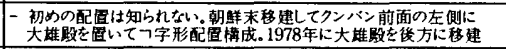 & \multirow{8}{*}{ 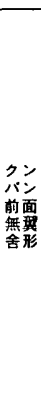 } \\
\hline 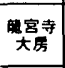 & 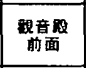 & (19) & 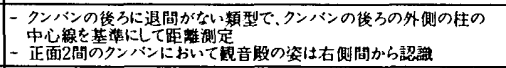 & \\
\hline 苓永寺 & $\begin{array}{c}\text { 大㳯僻 } \\
\text { 前面 }\end{array}$ & - & 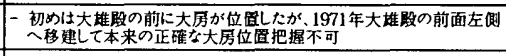 & \\
\hline 㫌院寺 & 梧繁面 & 8.2 & 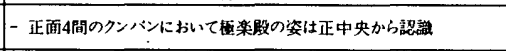 & \\
\hline 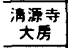 & 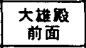 & 21 & - 正面3間のクンバンにおいて大婎殿の姿は中央問から㑇請 & \\
\hline 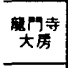 & - & - & 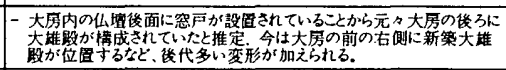 & \\
\hline 地滑寺 & - & - & 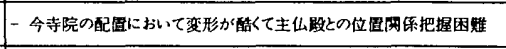 & \\
\hline $\begin{array}{ll}\text { 秦思寺 } \\
\text { 大房 } \\
\end{array}$ & - & - & 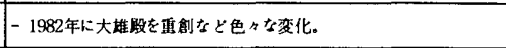 & \\
\hline 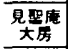 & 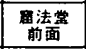 & 11 & 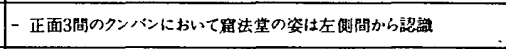 & \\
\hline 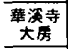 & $\begin{array}{c}\text { 大櫵殿 } \\
\text { 前面 }\end{array}$ & 17 & 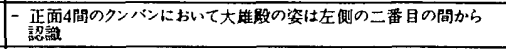 & 然 \\
\hline $\begin{array}{ll}\text { 光寺 } \\
\text { 光原 } \\
\end{array}$ & 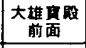 & 22 & 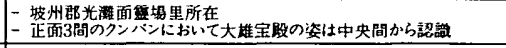 & 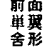 \\
\hline $\begin{array}{l}\text { 與国寺 } \\
\text { 大房 } \\
\end{array}$ & $\begin{array}{c}\text { 䔩師股 } \\
\text { 前面 } \\
\end{array}$ & 17.5 & 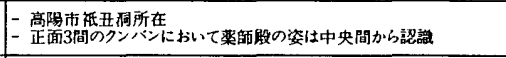 & \\
\hline 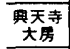 & 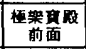 & 19.1 & 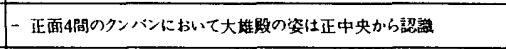 & \\
\hline 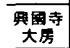 & 大堆离貶 & 19.1 & 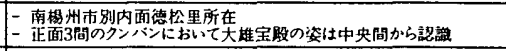 & $\begin{array}{l}\text { 前面 } \\
\text { 双 }\end{array}$ \\
\hline 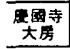 & 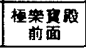 & 12.3 & 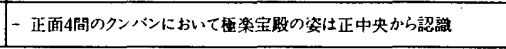 & \\
\hline
\end{tabular}

強占期に建立された興国寺(高陽市所在)の大房の場合にも、このよう大房構成 寺院の一般的な進入方式や平面構成計画がそのまま取られたことが見られる。

\section{2 外部空問特性}

朝鮮時代末期以来建立されたもので現存する大房と主仏殿が共に 構成されているソウル・京畿地域の寺院を対象として主仏殿に対する 大房の位置及び主仙殷と大房間距離を表4で整理した。(図1参照)

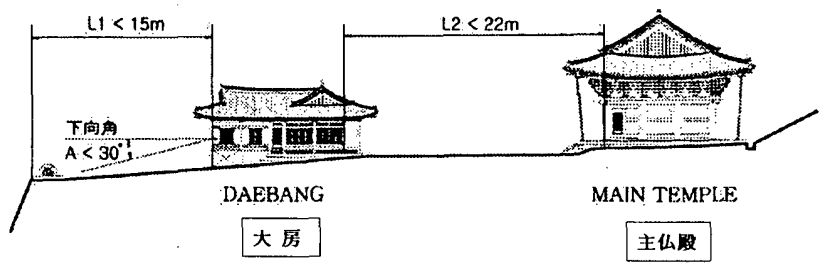

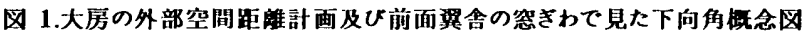

表4に整理された15個所の寺院の中で元っ配置がわからない石南寺、 龍門寺、地藏寺及び奉恩寺の場合を除外すると11個所の寺院すへてで 大房は主仏殿の前に位置していること的が見られる。またこの大房の位 置がわかる11個所の寺院のながで1971年に大房の位置が変えられた奉永寺 の場合を除外したら、10個所の寺院で大房と主仏殷との距離が見られる。

大房と主仏殿との距離を探ることに於いて先ず大房では大部分が念仏用 のクンバンの前後面に退間 ${ }^{17)}$ が形成される。この時、後面の退間が退抹楼に 構成された興天寺、華溪寺、普光寺、興國寺(南楊州市所在)の場合のように 、クンバン後面退間の內側から主仏殿を望むので、主仏殿と大房との間の 距離はクンバン後面の退間の內側にある柱の中心線から主仙殿前面の柱 の中心線までの距離を基準として整理した。これと共に龍宮寺の大房の 場合クンバン後面に退間が無くて、橛陀寺の大房の場合クンバンの内側中 間に柱が位置するから例外的にクンバン後面外側の柱の中心線から主仏 殿前面の外側の柱の中心線までの距離にして、その距離を整理した。

この場合、主仏殷と大房との間の距離(L2)は全て $22 \mathrm{~m}$ 以になるこ とがかかり、17〜22mまでの範围に入る場合を見ると日帝強占期に建 立された興國寺(高陽市所在)を含んで7個所で大部分を占めていて、 
残り3個所の寺では8～12mまでの範用に入ることが見られる。

これと關連して人間の䅐知覺的特性を活用した劇場計画の場合、客 席から舞台がよく見えることと同時に舞台の上の台詞伝達がそのまま 伝達される最大距離を $22 \mathrm{~m}$ までと規定して第1次許容限度距離に決めて いて、舞台の上の演技者の表情までも理想的に感想ができる生理的限

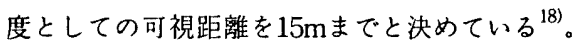

そして主仏㨄と大房間距離(L2)を見ると、第1次許容限度としての $22 \mathrm{~m}$ 以內に構成されている場合が7個所で、可視距離としての $15 \mathrm{~m}$ 以内に構 成されている場合が個所で現われている ${ }^{19)}$ 。また龍宮寺、華溪寺、普 光寺及び清源寺の場合 20 )、クンバンの內部に仏壇を㯰かないで主仏殿 を礼仏対象にして構成されている。

従って、このような大房と主仏殿との間の距離(L2)は主仏殿が大房 の主要な礼仏対象として主要舞台になる意図的な距離として寺院の配 置に適用されたことと解釈できる。

これと関連して大房のクンバンの內から主仏殿全体の姿が認識さ れる所は前面が偶数間になっているクンバンの場合、その規模が正面 2間になる龍宮寺大房では右側間から行われるが、その規模が正面4間 になる大房では左側から二つ目の間で行われている華溪寺大房を除外 したら残りの3棟では正中央から行われることが見られる21)。そして 奇数間になっているクンバンの場合、その規模はすべて正面3間にな っていることがかかり、この場合左側間から認識される見聖庵を除外 したら残りの3棟では中央間から行かれることが見られる。また日帝 強占期に建立された興國寺(高陽市所在)の大房の場合にも前面3間に なっているクンバンの中央間から主仏殿になる藥師虏が認識される( 写真1参照)。従って一部例外もあるが、全体的にはクンバンの正中央 を基準にして主仏殿と大房との距離が決められたことがわかる。

そしてその例外に属する場合を見ると、大房內のクンバンの前面が 奇数間になっている見聖庵では大房の左倒にこれより先に建立された 大雄殿があって、この二軒の建物の基壇がほとんど相接していること が見られる(図2参照)。これはすなわち笜法堂を大房の主仏殿にして 配置することに於いて敷地条件が大房內のクンバンの中央間に合わせ ることができない状況なので、クンバンと窟法堂との相互視覚的関係 を最大限考虑して仕方なく成り立ったことがかかる。また大房内のク

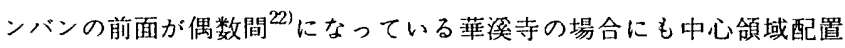
を見ると、大雄殷の前面に形成される狭小な中庭を效果的に確保する 必要性からクンバンの中央間ではなくて、左側から二つ目の間で大雄 殿との視軸を構成したことがわかる。

従ってこのように大房のクンバンの內の中央から主仏殿の姿が認識さ れるように視軸が配置計画に適用されていることと共に、その視距離(L2)が 第1次許容限度 $(22 \mathrm{~m})$ 以內ないし可視距離 $(15 \mathrm{~m})$ 以內として構成されてい ることから、過去クンバンの內部に仏塯が構成されなくて主仏殿を礼仏 対象にした可能性も排除できないし23)、クンバンの內部に仏增が構成された としても主仏殿をもっとも主要な礼仏対象にしようとする象街的な意味 が中心領域の配置計画に內在されていることと解釈することができる。

またこの大房と主仏殷の配置計画では,大房內のクンバンの正中央 を視軸の基準にしながら人間の視覚的特性を考虑して相互配置する基本 原則の以外に、周辺建物との関係や地形的な条件などの色々な狀況を総 合的に考虑して合理的に適用したことがかかる。

この地形的な条件までも総合的に考虑した奉例として特に普光寺と 興國寺(南楊州市所在)では大房を主仏殷と向かい合って配置しながら
表 5. 主仏殿の前面及び大房の前後面の庭の大きさ

\begin{tabular}{|c|c|c|c|c|}
\hline \multirow[b]{2}{*}{ 大原 } & \multirow[b]{2}{*}{ 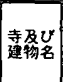 } & \multicolumn{2}{|c|}{ 摩の大きささ础さ $x$ 奥行) } & \multirow[b]{2}{*}{ 城考 } \\
\hline & & 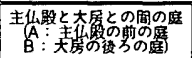 & 大房の前の唌 & \\
\hline \multirow{3}{*}{ 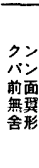 } & 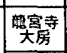 & $\begin{array}{l}(A: 14 \times 7.7 \\
B: 9 \sim 11 \times 2.5)\end{array}$ & $16 \times 9-11$ & - \\
\hline & 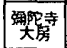 & $17 \times 3.9$ & - & 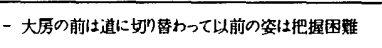 \\
\hline & 溜源 & $\begin{array}{l}(A: 8 \times 5 \\
B:(3.4 \times 8.1)\end{array}$ & - & 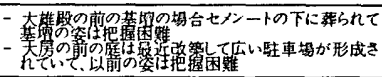 \\
\hline \multirow{4}{*}{ 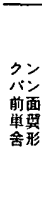 } & 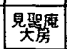 & $20 \times 8,8$ & - & 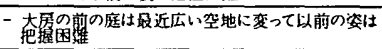 \\
\hline & 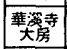 & $17 \times 8.5$ & $17.2[25] \times 13.5 \sim 15$ & (3) \\
\hline & 整类荓 & $18 \times 12-14$ & $22[30] \times 10 \sim 11$ & - \\
\hline & 興刑寺 & $14.8 \mathrm{~m} \times 10 \mathrm{~m}$ & $13.7[21] \times 11.17$ & 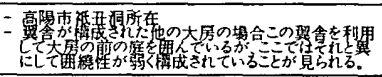 \\
\hline \multirow{3}{*}{ 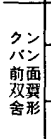 } & 興芺寺 & $10.8 \times 9$ & $11[24.5] \times 9 \sim 11$ & (1) \\
\hline & 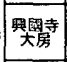 & $11 \times 12$ & - & 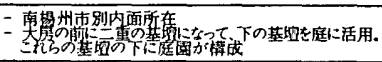 \\
\hline & 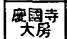 & $24.5 \times 5.6$ & $8[22] \times 6.5$ & - \\
\hline
\end{tabular}

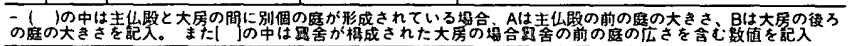

も地形上の等高線を配虑することによって、敢えて幾何学的な軸に固 執しないで、地形毁損を最小限になるように幾らかの届折軸を受容し

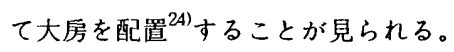

従ってこの分析内容を通じて大房の外部空間では合理的な視覚計 画や総合的な周辺状況の考虑やこれによるからの環境親和的な配置計 画が共に適用されて計画されていることを考察することができる。

一方主仏殿とその前の大房は庭を中に㯰いて中心領域を構成す るので、主仏解の前面と大房の後面の間に庭が構成 ${ }^{25)}$ れていること がわかり、これと共に大房の前面にも大部分庭が構成されていること が見られる。表5ではこの庭の大きさを整理した。

表5に現れた庭の大きさを見ると、主仏殿と大房の間に位置した庭 ${ }^{26)}$ の場合、その広さは $11 \mathrm{~m} か ら 24 \mathrm{~m}$ まで分布し、その奥行は $4 \mathrm{~m} か ら 14 \mathrm{~m}$ まで分布していて、どんな一定の規則性は見られない。

表5ではまた大房の前にある庭に対して探れる。これを見ると、そ の広さが $8 \mathrm{~m} か ら 22 \mathrm{~m}$ で分布するし、その奧行は $6.5 \mathrm{~m} か ~ 15 \mathrm{~m}$ までと して15mの內に分布していて、多くはないが特にその奥行が11mを前 後して集中している。そしてこれは日帝強占期に建立された興國寺( 高陽市所在)の大房でも同様に適用されている。このように大房の前 の庭の奥行が後ろの庭の奥行と比へててそんなに深くなく $15 \mathrm{~m}$ 以とし て $11 \mathrm{~m}$ 前後して棈成されていることは翼楼の眺望機能を充足させる ための計画に起因したことと見ることかできる27。この場合翼楼が構 成された大房を対象にして、翼楼の前面の外側柱の中心線から庭の端 までの長さ(L1)と翼樓の高さとの関係より、翼楼の空ぎに近寄って座

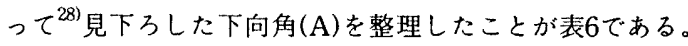

表6から下向角 $(\mathrm{A})$ は $30^{\circ}$ 以內として主に $13^{\circ}$ から $24^{\circ}$ までの範囲になって いて、これは日帝強占期に建立された興國寺(高陽市所在)の大房でも 同様に適用されていることが見られる。さて人間の目において垂直面 上の視界はほとんど $60^{\circ}$ だから ${ }^{29)}$ 、視軸を中心にして $30^{\circ}$ 以內の下向角 の範围に物体がある場合、頭または瞳を動かなくても自然に見られる ことがかる。従ってこの事奏と共に接待用翼楼での眺望の重要性を考虑 すると、その遺構数が充分ではないが、朝鮮時代末期から日帝強占期まで の寺院の大房の場合、翼楼の高さと翼楼の前の庭の奥行は詳しく事物 が見られる可視距離 $(15 \mathrm{~m})$ や見易く望むことができる下向角 $(\mathrm{A})$ を共に 充足するように計画されたと解釈される。さらに可視距離の場合、そ の最大距離 $(15 \mathrm{~m})$ が翼楼の前ではなくて、クンバンの前面退抹楼の前で 
表 6. 大房の翼楼の空ぎわで見た視軸に対する下向角

\begin{tabular}{|c|c|c|c|c|c|c|}
\hline 太呞 & \begin{tabular}{|c|} 
寺刹及 \\
速物名 \\
\end{tabular} & \begin{tabular}{|c|} 
翼の楼傯面の \\
行* (1) \\
\end{tabular} & 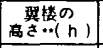 & $\begin{array}{c}\text { 貝の高き } \\
(\mathrm{h}+0.75)\end{array}$ & 下向解度 & 诺考 \\
\hline \multirow{4}{*}{ 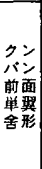 } & 㮂哭磨 & - & 2.43 & 3.18 & - & 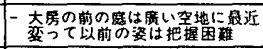 \\
\hline & 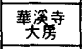 & $12-13$ & 2.25 & 3.0 & $13^{\circ}-14^{\circ}$ & 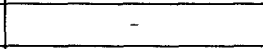 \\
\hline & 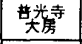 & $7-9.2$ & 3.3 & 4.05 & $238^{\circ}-30^{\circ}$ & - \\
\hline & 興宩寺 & 10 & 2.4 & 3.15 & $17.5^{\circ}$ & 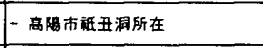 \\
\hline \multirow{3}{*}{$\begin{array}{l}\text { クン } \\
\text { 前面 } \\
\text { 知 } \\
\text { 舍形 }\end{array}$} & $\begin{array}{l}\text { 興天寺 } \\
\text { 大枋 } \\
\end{array}$ & \begin{tabular}{|l|}
$8.5 \sim 9.0(15$ \\
$6.8-7.1(1)$
\end{tabular} & 2.3 & 3.05 & $\begin{array}{l}187^{\circ}-197^{\circ} \\
232^{\circ}-242^{\circ}\end{array}$ & 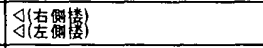 \\
\hline & \begin{tabular}{|l} 
興阉寺 \\
\end{tabular} & - & 2.1 & 2.85 & - & 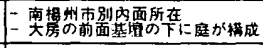 \\
\hline & 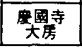 & 6.32 & 1.47 & 2.22 & $19.4^{\circ}$ & 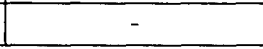 \\
\hline
\end{tabular}

適用されていて、これから翼楼はもちろんのことで、大房のクンバン の前面退抹楼にも座って庭の端の花のような造景植栽を詳しく感想す ることができるように視覚的に配虑したことがわかる。

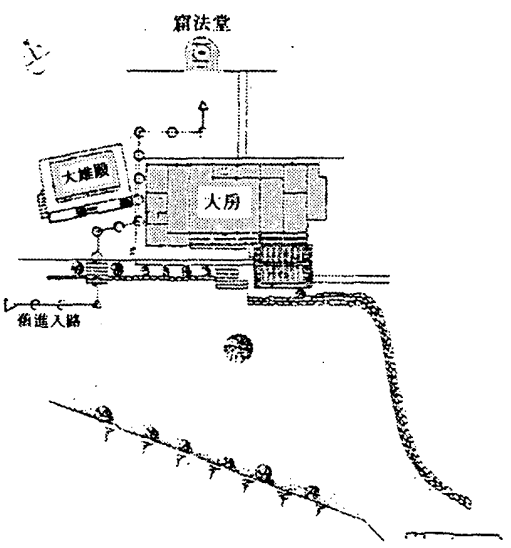

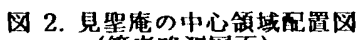
(䇠者略测四面)

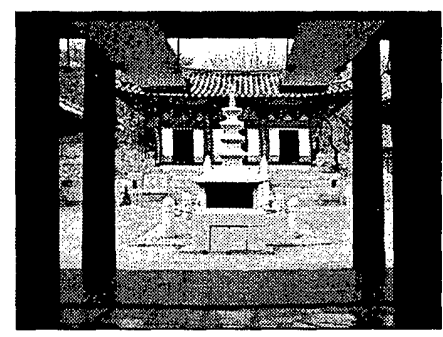

写真 1. 高際興國寺の大原の クンバンの内から見た萊凘殿

\section{4. 結諭}

19世紀から1945年までのソウル・京畿地域の寺院で新たに現れた 新類型の仏殿になる大房を対象にして、その外部空間を分析して、次 のような空間の特性がわかる。

まず、大房が構成された寺院での中庭進入は主仏殿と大房が共に丵 成された寺院も主仏殿が大房になる寺院のいずれの場合も左側進入方 式を一般的な原則にした。

次に大房と主仏殿が共に構成されている寺院の場合、大房は主仏殿 を実際的或は象徵的な礼仏対象にして棈成されている。その相互距離 は全て $22 \mathrm{~m}$ 以內で、主仏殿で仏教儀式が行われる時大房內のクンバンにい る人々がこれを視聴覚的に認識することができる距離以内に構成されている。
それで大房と主仏殿の間に位置した庭の場合、仏教行事の時多い群衆 の収容と法要式舉行などに有效な外部空間に活用されるので、このような機能 を収容しながら中心領域の地形的条件などを考虑して適切に構成されている。

これと共に翼楼が構成された大房では翼楼の高さや翼楼前面の庭の 奥行の構成に於いて詳しく見られる可視距離 $(15 \mathrm{~m})$ や見易い眺望角度にな る下向角 $\left(30^{\circ}\right)$ を同時に充足させるように計画されていることが見られるの で、大房の前の庭では眺望計画を重視してその空間が構成されたこと がかかる。そしてこの事実から当時匠人が人間の視知覚的認知特性を 充分に理解して外部空間の計画に適用した一端を見ることができる。

これから朝鮮時代末期当時、規模がある大房構成寺院の中心領域の配置 計画を推定すると、主仏殿を大房の夷際的或は象徵的な礼仏対象にして 、大房のクンバンと主仏殿の正中央を基準軸にしながら人間の視知覚的な 認知距離を考慮して大房と主仏殷の位置を定めたと言うものである。こ れに地形毁損を最小限になるように地形的特性や周辺環境などを総合 的に考虑してその建物を座らせると共に、その間には法会及び大粮の為の 実際的用度の庭を、大房の前には眺望など休息機能の庭を設けると判断 され、これは日帝強占期にも持続されたことがわかる。

\section{謝譬}

Let me thank Prof. Joo, Nam Chull of Korea Univ. who advised this paper and Prof. Katagiri Masao and Dr. Hamajima Kazunari of Nihon Univ. who gave me much advice and a chance of post-doctoral study.

生

1）万会田沓は念仏会開催時、念仏堂すなわち大房で万日間念仏会を維持するこ とができように、寺院とは別に全然独立的に経営きれた大原所屬の田沓である。

2）高橋亨、李朝仏教、豊鳥：国害刊行会、昭和48年、p.774参照

3）大房と関連して、既存の論文として、“A Study on the Characteristics of the Korean Buddhist Temples from the Mid-19th to the Mid-20th Century(金成 都、高麗大博士学位請求論文)”では韓困の伝統的な仏殿と共に朝鮮時代末期新 たにソウル・京畿地域に現れた仏殿になる大房を対象にして、当時の仏殿の特性が 研究された。“A study on the Daebang Building in Temples of Seoul and Gyeonggi Province late in the Joseon Dynasty(朱南哲-金成都, 大韓建築 学会論文集)”で大房の形成背景と定義及び特性なとが考察靲、“A Study on the Daebang Design in Temples of Seoul. and Gyeonggi Province in the Kojong Era(金成都・朱南哲，大韓建策学会論文集)"では高宗朝に建立きれた 大房を対象にして大房の意匠上特性の分析と共に、当時大房以外の伝統的な寺院 の仙殿との差異点当研究きれた。れてで."A Sludy on the Constitution and Transition of the Geonbong Temple in the late Joseon dynasty(金成都, 大 韓建築学会論文集)”では大房の起源に対して考察誵、“A Study on the Characteristics of Space of the Daebang Building in Buddhist Temples of Seoul and Gyeonggi Province in the late Joseon Dynasty(金成都, Yonsei University Press)”では朝鮮時代末期の大房の内外部の空間の特性が発琶希れ た。だA Study on the Characteristics of the Floor Plan of Daebang Building in Buddhist Temples of Seoul and Gyeonggi Province from the 19th to the Mid-20th Century(金成都・来南哲，大韓建築学会論文集)”では 進入動線及び機能計画と関聯した大房の平面空間の特性が研究された。

4) 1910年以来から1945年まで大房が建立された記録がある寺では興龍寺(抱川 郡二東面都平里 $28 ， 1918$ 年大房を建立したか，6・25戦争て焼失)、上院黁( 揚本郡龍門面延尌里山72、1918年大房を建讧したが、6・25戦争で焼失)、觀 音寺(ソウル冠岳區南峴洞519-3、1924年大房建立)、戀主庵(果川市中央洞85 -1、1929年大房15間再建)、奉國寺(ソウル战北區貞陵2洞637、1938年大房建 立)、三㕵庵(ソウル渞峰區水䠯2洞488、1943年大房建立)、奉元寺(ソウル西 大門區奉元洞山1、1945年大房を堆築したが、6・25戦争で焼失)などがある か、この寺院の大房は現存しない。

5）高陽市祇丑洞に位置する興國寺の大厉はクンバン(モンチェの大きい念仏用房)前

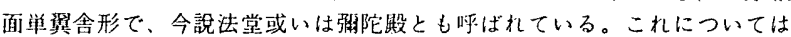
金成都の $r_{A}$ Study on the Characteristics of the Korean Buddhist Temples from the Mid-19th to the Mid-20th Century _ p.127 参照

6)「モンチェ(品暗)」は建築物に於いて中心になる部分在称する用語で、大房の前 後面の翼舎のような突出した部分を除外した家葲の中心になる部分を意味。

7）位置の場合、この論文では建物の前に位㯰した就察者の視点を中心にして整理。

8)これは寺院の経消力や接客の重婜度に従って沃められたことである。 金成都、前揭畫、 $\mathrm{p} .75 \sim 77$ 参照

9）在側の接待用の翼楼を省略して、左側の僧仍怵息州の翼楼だけで棈成され 
ることはないので、接客の重要性を知ることができる。

10）一般的にクンバン前面の翼舍は頌斜地を活用して楼に構成されているか、雲 水庵の大房では傾斜の無い平地に位置しているから、左側の翼舍が抹楼房に構 成されて、右側の窗舍が温突房に構成されている変形した型式が見られる。一 方內部を全て一つの部屋に改造する以前の興國寺(南楊州市所在)の大房では 左側の翼舍が楼に構成されていて、右側の翼舍の場合は違って房に構成されて いるが、元っは左右兩翼舎全て楼に構成されたと思われる。

11）ここでは朝鮮時代末期に念仙堂の責任者として独立的な生活を営為したのみ ならす、その職を法孫に变り渡して世暜した化主を言及する。“金成都、前揭 書、p.78 註) 171 参照”

12）日帝強占期に建立された大房では奉恩寺選佛堂、開運寺大筧樓、興國寺橛 陀殷(高陽市所在)がある。この中で開運寺の場合、大覺樓が移建されて元 の配置を把握することができない。奉恩寺の場合、1982年に大雄殷が大き い規模で再建されてから、中心領域での以前の元の配㯰を把握することができ ない。従って興國寺だけで当時の配置計画を見ることができる。この場合 現存遺構が1個所しかないので、朝鲜末期建立された大房と比較して変化が あるのかを中心に考察する。

13）主仏殷は阿弥陀仏が奉安された極樂殷とか岈迦が奉安された大雄殿などのよ うに、寺院の中でその位階が最高の仙殿を称する。またその他の様々な仏教 殿閣を仏殷と称する。日本の場合、禅宗の仏殿、密教の本堂などを通称して、仏堂と することとは差がある。

14）これと共に化主用の僧房の場合、化主が念仏用のクンバンや接待用の楼を 兩々相まって容易に管理ができるようにこれらの中に位置させて合理的に 動線計画をしたことがかかる。またクンバンの側に位㯰した台所の場合、 念仏大采のための食事供養の便利を謀るように動線構成をしたことがわか る.これに対してばA Study on the Characteristics of the Floor Plan of Daebang Building in Buddhist Temples of Seoul and Gyeonggi Province from the 19th to the Mid-20th Century" 參照

15）雲水庵の大房の場合には右側に補助台所を左側に主台所を構成した特異な形 態だが、今は左側の主台所だけがそのまま残っていて、右側のは部屋に改 造されている狀態である。奉恩寺の大房の場合も右側進入の場合であるが、 朝鮮の初めの念仏宗刹になる乾愿寺のように、主仏殿が主な軸に構成きれながら、 大房もまた一つの軸に構成されて、二つの軸に構成されていることが見られる。それ で大房の右則を通して他の佛殷へ接近するように構成されている。

16）龍門寺の場合、大房内部仏壇後面に出入門が構成された事実と大房が建立さ れた 1 年後に大雄殿が立てられた事実から大房の後ろ側に主仏殿が構成された ことが推定された(金成都、前揭畫、p.112、註)239参照)。この場合を包含する と11個所の寺で主仏殿の前に大原が構成されたことが確認される。

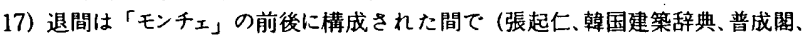
p.30 参照)、ここには退梁が構成される。

18）建築資料研究會編，建築設計資料集成 4 ，同友出版社，1984，p.123 これと関連してHarold Burris-Meyer及びF.G.Coleの場合にも俳優の扮装と表 情の微細な変化が読み取れる限界距離を507イート(15.2Am)と規定していて、75 フィート $(22.86 \mathrm{~m})$ を最大可視距離と提案している （Joseph De Chiara・John Callender、Time-Saver Standards for Building Types、p.363参照)。 これは外部空間に対しても同様に適用されることが見られる。芦原義信は人 間の顔の識別ができる外部空間に於いての距離を70〜807ィート(21.336〜24.3 $84 \mathrm{~m})$ と規定しながら、大きい空間においてこのような範囲に材質の変化とか フロアの高さの差を置くと生動感がある空間に新たになることをはっきりし ている (芦原義信、建築の外部空間、p.56 59 参照)。

19）人間の視知覚的認知特性を適用して、劇場建築の場合その内部の空間構成に活 用することに対して、大房建立寺院の場合その外部の空間構成に活用することがか かる。当時大房建立寺院が都市の騒音源と隔離されて静かな山地に位置した地理 的特性を活用して構成されたことがかかる。またこのよう人間の視知覚的認知特性を 主仏殿と大房間の距離計画に活用した事実から、当時匠人の合理的な思考体系の 一端が読み取れる。こと関連して、メーター法が使かれる以前、人間の身体が建築計 画の基準単位に成っていた時代に、長い年月を経て匠人が体得して活用した建築の 数値計画の場合、今日のメーター法を基準にして多くの人っを対象にして身体や視覚 的特性などを分析した結果としての人体工学の結果と比較して、巨視的数值計画の 側面で一致することがあるのは当然と言われる。のような観点から大房の外部空間 の相互距離の分析を通して、人間の視知敩的認知特性が当時の外部空間の計画 に活用されたことを確認することができ、これは当時匠人が人間に関する特性を体系 的に理解していることを立証する。それで大房と劇場計画いずれも人間を対象にしてそ の視知覚的特性を活用して計画することによって、その結果の一致することが見られる。

20）特にこの寺の場合、主仏殿大大房との間の距離が第1次許容限度になる22m以 內として、17２2mまでの間に構成されているのが注目に值する。

21）正面4間のクンバンの場合、正中央は柱が位置する。しかし大衆とか念仏僧が大房 のクンバンの内から主仏殿を見ながら念仏をするとき、この中央柱のすく左右の間に 構成された空戸を通して見渡すことは当然と言われる。こ場合、主仙殿の正面の姿 は大房から離れた距離と人間の目が持つ視覚的限界によって、クンバンの前面が奇 数間になっている大房の場合とその認識に於いての差異が感じれないことがかか る。従ってこれとその必要な部屋の規模などを顧府して計画されたと言われる。

22）クンバンの前面が偶数間になっている大房として主仏殿との視軸がクンバンの正中
央で形成していないことには華㴽寺以外に龍宮寺もある。ところで大部分の大房内の クンバンの前面の規模は3間以上になっていることに対して龍宮寺の大房ではクンバ ンの前面がたた2間に構成されていて、クンバンの右側間の後ろの空戸を明けたときそ の空户を通して主仏殿の全体の姿が見られるようなっている。

23）華溪寺の大房の場合、過去クンバンの內部に仙壇がなくて大婎殷を礼仏対 象にしたが、今はクンバンの內部に仏壇を設置しているところで、他の寺 院の大房でもこのような可能性を排除できない。

24）また大房の前面に構成された翼舎の場合、大部分が地形の高低の差を利用して重 層の翼楼に形成されている。しかし敷地が平らになっている雲水庵の場合、このような 構成が困るから、敢えて敷地を切土とか盛士をして人工的に高低の差を作って重層の 翼楼に構成しないで、平地でただ単層の翼舎に構成しながらフロアを抹楼房に作った ことも地形的状況を配慮した結果の一つと見られる。

25）大部分の大房の後ろと主仏殿の前との間の空間に庭が形成されて中心領域が構 成されるが、例外的に龍宮寺の場合大房の後ろにはほとんど通路に用いられる庭た けで構成されていて、主仏般になる観音殷の前に重な庭が形成されていることが見ら れる。また清源寺では大房の後ろと主仏殿の前の間の空間に庭が形成されながらも 主仙殷になる大雄殷の前に別個の小さい庭が構成卆れている。

26）大房が建立きれている寺院を含んで全ての韓国仏教寺院ではこの中心領域の庭か 多い大衆を収容し、仏教行事の時法要式を行う有用な空間としての役割をする。

27）クンバン前面の右側の翼楼の機能は眺望及ひ接待のためのことで、これに 対しては大房の形成背景と定義(金成都、前揭書、p.74〜 75)参照

28）当時の韓国人を対象にして座っている時の目の高さの基準寸法に対しては催相雪の 論文を参照した。彼は日本人になる久保が1913年に朝鮮の大人の身体を調査した資 料をその基礎にしながら、1986年に発行された国民標準体位報告書の韓国の人体 計測値を共に参考して朝鮮時代の韓国人の体位基準を捜し出した。れに因ると座つ ている時の目の高さは女の人の場合 $70.2 \mathrm{~cm}$ 、男の人の場合 $76.8 \mathrm{~cm}$ 算出された がこの論文では人に因る差やいくら位の融通性を考慮して坐っている時の目の高さ を二尺半になる75cmにした。

29）芦原義信、前揭害、p.52

\section{至考文献}

1)「見聖庵雨花樓記」，高宗23年(1882)

2)「高露山普光寺三重建樓上樑文」，高宗6年(1869)

3) 「興國寺萬藏樓房重建記功文」, 高宗16年(1879)

4) 京畿道, 京畿道指定文化財 賽測調查報告書 上·下，1996

5）京畿道，京畿道指定文化財 實測調查報告畫，1989

6) 京畿道, 畿內寺院誌, 1988

7) 사찰문화연구원, 전통사찰총서[3] 경기도, 사찰문화연구원출판국, 1993

8) 사찰문화연구원, 전통사찰총서미 서울의 전통사찰, 사찰문화연구원출판국, 1996

9) 사찰문화연구원, 전통사찰총서[5] 인천-경기도의 전통사찰 $\mathbb{I}$, 사찰문화 연구원출판국, 1995

10) 서울특별시, 奉恩寺 實測調查 報告書, 1990

11) 서울특별시，華溪寺 實測調査 報告書, 1988

12) 서울톡별시, 興天寺 實测調査 報告書, 1988

13）水原市史編筑委員會，水原市史，1986

14) 芦原義信(Ashihara Yoshinobu)：建築의 外部空間, 기문당, 1985

15) 金成都, rA Study on the Characteristics of the Korean Buddhist Temples from the Mid-19th to the Mid-20th Century - Focused on Seoul and Gyeonggi Province」, 高麗大博士學位請求論文, 1999.7

16) 金成都 : A Study on the Characteristics of Space of the Daebang Building in Buddhist Temples of Seoul and Gyeonggi Province in the Late Joseon Dynasty. Post proceedings of the World Conference on Cultural Design, Yonsei University Press, pp.650 692, 2001

17) 金成都 : A Study on the Constitution and Transition of the Geonbong Temple in the late Joseon dynasty, 大韓建築學會論文集, v.18, n.2, pp.101 108, 2002. 2.

18) 金成都, 朱南晢 : A Study on the Daebang Building in Temples of Seoul and Gyeonggi Province late in the Joseon Dynasty, 大韓建築學 會論文集, v.15, n.4, pp.163 171, 1999. 4.

19）金成都, 朱南哲 : A Study on the Characteristics of the Floor Plan of Daebang Building in Buddhist Temples of Seoul and Gyeonggi Province from the 19th to the Mid-20th Century, 大韓建築學會論文集, v.18, n.7, pp.67 74, 2002. 7 .

20) 朱南哲, 金成都 : A Study on the Daebang Building in Temples of Seoul and Gyeonggi Province late in the Joseon Dynasty, 大韓建築學 會論文集 v.14, n.11, pp.229 240, 1998.11 .

21) Choi, Sang-Hun : A Study on the Relationships between Human Dimensions and Interior Space of the Korean Traditional Residential Architecture, 大韓建築學會論文集 v.10, n.11, pp.189 198, 1994.11.

22) Chiara, Joseph De - Callender and John Hancock:Time-Saver Standards for Building Types, 2nd Edition, McGraw Hill Book Co.. 1980 


\section{英文要約 (Summary)}

Daebang in Seoul and Gyeonggi province, evolved from the ru(樓) which was located at the front of the main temple such as Geukrakbojeon(極樂寶殿) under the necessity of space for yeombul (i.e. pray to Buddha) and reception by the yeombul-prevalent and reception-valued social background in the late Joseon (Chosun) dynasty, was a temple for yeombul.

This building was made in the main domain of sachal (寺刹, i.e. a generic name of Buddhist precincts consisting of temple dormitories and various kinds of temple buildings) as one of 3 important temples together with Jwaseondang(坐禪堂, i.e. a generic name of temple building for meditation) and Ganghakdang (講學堂, i.e. a generic name of temple building for lecture) in those days. And under the financial support such as manilhwe-jeondap (萬日會田永, i.e. dry fields and paddy fields which were donated to the monk to support yeombul for 30 years), it was managed independently in a sachal by hwaju (化主; an official title of the monk in charge in those days). Therefore, the formation of space of this building having been affected by these, it became a complex temple equipped with a kitchen and monks' bedrooms in itself.

Daebang is composed of one keunbang (one large room for praying to Buddha), toetmaru(es) (退抹樓, i.e. the floor made in front or rear toetgan) made in front or in the rear or both in front and rear side of it, monks' rooms for hwaju and other priests, a right side wing room for guest. reception and a left side wing room for monks' refreshment, and other auxiliary rooms such as storage and attic. Among these, a keunbang, toetmaru(es), a room for hwaju, a kitchen and auxiliary rooms are its basic elements and it could be divided into three types according to the number of projecting side wing room attached to the basic elements of 'it: First, there is a building type attached two side wing rooms in front of keunbang in addition to the common elements, for example those of Cheonchuksa, Heungcheonsa and so on. Second, there is a building type attached one side wing room in front of keunbang in addition to the common elements, for example those of Hwagyesa, Bogwangsa and so on. The third, there is a building type with no side wing room in front of keunbang, for example those of Weontongam, Yonggungsa and so on

This study aims at finding out the characteristics of outer space of the daebang temple in Seoul and Gyeonggi province from the 19th to the mid 20th century by analyzing the existing 19 buildings.

This study shows that the daebang was a rational and green architecture and it could be summarized as follows:

The standard type of approach to the main domain in the sachal (寺刹) with daebang was the left-side access of daebang. In this case, both the master's room for hwaju and a projecting-side wing room for reception that needed privacy were on the right side, the opposite of the road, to secure a private life. With this, we could see that the rational planning of space was accomplished from the facts that by locating the hwaju's room between the side wing room for reception and the keunbang for yeombul it was possible for hwaju to control these two rooms effectively and by placing a kitchen beside a keunbang it was possible for servants to maximize a good service for food in its floor plan.

In the central domain in temples having been composed of both a main temple and a daebang, the former was regarded as a practical or symbolic worship object of the latter and these two buildings were settled within the distance of 75 feet each other. It is the maximum length between a stage and an auditorium for us to see and listen to the actors in designing a theatre. In an aspect of human visual perception, it is not different with the plan of a theater. With this, the degree of view looking downward at the front window of the side wing room(s) of daebang was usually within the limit of $30^{\circ}$ and this downward angle permits us to look out easily without any movement of one's head or eyes, and the distance from the window of the side wing room to the brink of the front court of it was within the limits of $15 \mathrm{~m}$, the maximum length to see the details of the actors in designing a theater. These tell us that the architects in those days understood the characteristics of human optical perception and utilized it.

Besides these scientific and rational plan in which the human visual perception was considered, we could see a phase of green architecture from the facts that the exact geometric optical axis was not urged between a daebang and a main temple and these two buildings were placed in sympathy with the geographical features to preserve the nature, and, as a result, it was possible to minimize damage to the earth.

（2002年 8 月 31 日原稿受理， 2003 年 1 月 30 日採用決定） 